\title{
New records of polychaetes (Annelida) for northern Ecuador
}

\author{
BERENICE TROVANT ${ }^{1}$, RODOLFO ELÍAS ${ }^{2}$, MARÍA E. DIEZ ${ }^{1}$ AND JESÚS A. DE LEÓN-GONZÁLEZ ${ }^{3}$ \\ ${ }^{1}$ Centro Nacional Patagónico (CONICET), Boulevard Brown 2915, U9120ACF Puerto Madryn, Chubut, Argentina, ${ }^{2}$ Departamento \\ de Ciencias Marinas, Universidad Nacional de Mar del Plata, Argentina, ${ }^{3}$ Facultad de Ciencias Biológicas, Universidad Autónoma de \\ Nuevo León, México
}

\begin{abstract}
Even though Ecuador is one of the twelve mega-diverse countries in the world, the polychaetes are still poorly known. Twelve polychaete species, namely Hemipodia pustatula (Glyceridae); Microphthalmus arenarius (Hesionidae); Scoletoma zonata (Lumbrineridae); Nereis riisei, Pseudonereis gallapagensis (Nereididae); Armandia salvadoriana, Euzonus mucronata (Opheliidae); Phyllodoce multiseriata (Phyllodocidae); Pisione longispinulata (Pisionidae); Malacoceros indicus, Scolelepis (Scolelepis) acuta (Spionidae) and Opisthosyllis arboricola (Syllidae) are newly reported in the intertidal sandy beaches of Bunche $\left(0^{\circ} 39^{\prime} 01.98^{\prime \prime} \mathrm{N} 80^{\circ} 0^{\prime} 55.01^{\prime \prime} W\right)$ and Cabo San Francisco $\left(0^{\circ} 38^{\prime} 16.35^{\prime \prime} \mathrm{N} 80^{\circ} 03^{\prime} 14.07^{\prime \prime} W\right)$, Esmeraldas Province (Ecuador). Furthermore, an amended diagnosis of Pisione longispinulata is presented.
\end{abstract}

Keywords: eastern Pacific, sandy beaches, intertidal, marine worms

Submitted 11 October 2011; accepted 4 November 2011

\section{INTRロDUCTIDN}

Ecuador possesses a great variety of coastal environments allowing for a high diversity of marine species. However, systematic studies on marine invertebrates are scarce, especially in polychaetes. In continental Ecuador, only 29 families, 53 genera and approximately 75 species of polychaetes are recorded so far. Hartman (1939) pioneered polychaete studies by describing four new species and ten new records from Puna and Santa Clara Islands (Guayas Province). Later, Cruz et al. (1980) reported four new records from benthic samples collected on the Estero Salado of Guayaquil Gulf. In the same Gulf, near that area, 29 species of polychaetes were identified by Villamar (1983), one of which was a new species of Grubeulepis. The same author in 1989 reported nine new records at Canal del Morro and Jambeli in the Guayaquil Gulf. In the intertidal zone of Monteverde (Guayas Province), Villamar \& Cruz (2007) later reported three new records for Ecuador. A new species of Australonuphis used as fishing bait, was described by de León-González et al. (2008) in Santa Elena Bay (Guayas Province). In northern Ecuador, very little is known about this group, and only one ecological study has been carried out by Villamar (2006) in the intertidal zones of Manabi and Esmeraldas Provinces. In that paper, the author reported 12 genera and 27 species, of which 14 constituted new records for this country.

In order to increase the knowledge about this group of invertebrates on the Ecuadorian coast, we herein provide a checklist of the polychaete fauna from Bunche and Cabo
San Francisco Beaches (Esmeraldas Province), northern Ecuador.

\section{MATERIALS AND METHDDS}

Samples were collected in March 2009 (dry season) in the intertidal zone of two sandy beaches: Bunche $\left(0^{\circ} 39^{\prime} 01.98^{\prime \prime} \mathrm{N}\right.$ $80^{\circ} 0^{\prime} 55.01^{\prime \prime} \mathrm{W}$ ) and Cabo San Francisco (o $38^{\prime} 16.35^{\prime \prime} \mathrm{N}$ $80^{\circ} 3^{\prime} 14.07^{\prime \prime} \mathrm{W}$ ) located in the Esmeraldas Province, of northern Ecuador (Figure 1). The beach dynamics are different. Bunche is characterized as a low energy beach, a calm and protected area, with soft sloping banks and very fine particle sand, while Cabo San Francisco is characterized as a high energy environment (subjected to frequent and severe storms), with high slopes and larger than average grain size. Fresh water discharges affect both beaches. Sediment samples were sieved through a $1-\mathrm{mm}$ mesh. All the polychaetes species were separated from the sediment, except one: Phyllodoce multiseriata Rioja, 1941, which was found in tidal pools at low tide. Specimens were fixed in $10 \%$ formalin and later preserved in $70 \%$ ethanol. The identifications were made using the taxonomic keys of Fauchald (1977) and de León-González et al. (2009). Samples were deposited at the Polychaetological Collection of the Universidad Autónoma de Nuevo León (Phyllodoce multiseriata, UANL 7803; Opisthosyllis arboricola, UANL 7804; Hemipodia pustatula, UANL 7805; Nereis riisei, UANL 7806; Pseudonereis gallapagensis, UANL 7807).

\section{RESULTS}

Twelve polychaete species belonging to twelve genera and nine families were recorded from Bunche and Cabo San Francisco Beaches. This list includes eleven new records 


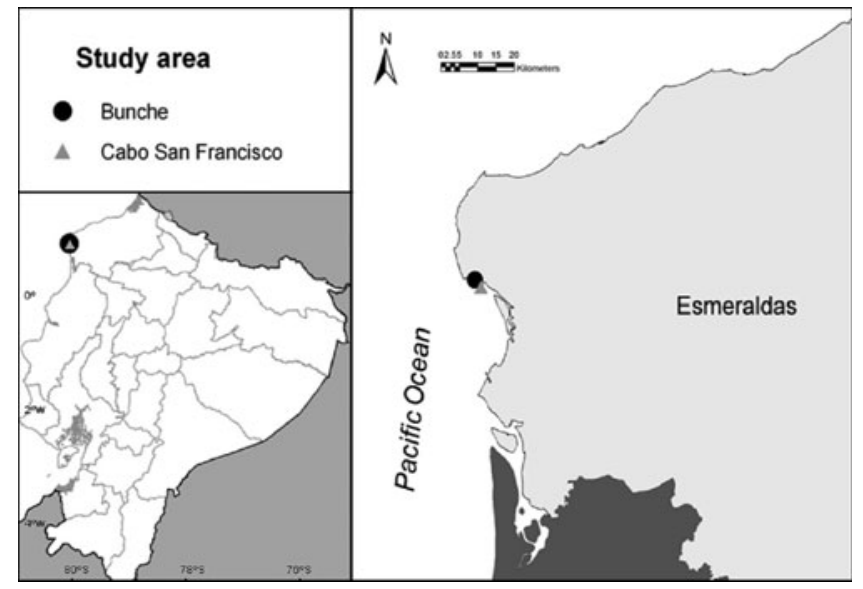

Fig. 1. Map of Ecuador indicating the sampling sites, Bunche and Cabo San Francisco Beaches.

for Ecuador and one, Nereis riisei, for northern Ecuador. Short descriptions of the polychaete species sampled for this study are given below.

\section{SYSTEMATICS}

Family GLYCERIDAE Grube, 1850

Genus Hemipodia Kinberg, 1865

Hemipodia pustatula (Friedrich, 1956)

(Figure 2A)

Hemipodus pustatulus: Friedrich, 1956: 61, figure 4A-C.

Hemipodus ciliatus: Hartmann-Schröder, 1959: 150, figures $128-131$.

Hemipodus longipapillatus: Hartmann-Schröder, 1965: 150 , figures $118-121$.

Hemipodia pustatula: Böggemann \& Eibye-Jacobsen, 2002: 83 , figures $136-138$.

\section{MATERIAL EXAMINED}

Bunche Beach, two complete specimens, six anterior and three posterior fragments, 21 March 2009, coll. Berenice Trovant and Santiago Tineo.

\section{DIAGNOSIS}

Up to $40 \mathrm{~mm}$ long and $1 \mathrm{~mm}$ wide, 118 chaetigers. Live specimens bright red; preserved specimens orange to brown. Mandibles with simple rod-like ailerons. Pharynx covered by two types of papillae, with ' $U$ '-shaped ridges: digitiform ones with 10-15 ridges and conical ones with 8-10 ridges. Branchiae absent. All parapodia uniramous, with one long subtriangular prechaetal lobe and one rounded to triangular postchaetal lobe; prechaetal lobe with digitiform distal process from median parapodia to the posterior end of the body. Parapodia with one aciculum and compound spinigers. Globular dorsal cirri. Triangular ventral cirri on anterior parapodia, on median parapodia subulate and on posterior parapodia rounded to oval. Pygidium unknown.

\section{DISTRIBUTION}

Pacific Ocean: México (Bahía Kino and Mazatlán), El Salvador (Metalio, Acajutla, Las Salinas, La Libertad, San Diego, Toluca,
Amate Campo, Las Hojas, Los Blancos, El Zapote, La Chepona and El Cuco), Costa Rica, Panama and Chile (Bahía San Vicente); Atlantic Ocean: Caribbean Sea, Costa Rica, Panama and Brazil (Paranagua).

Family HESIONIDAE Sars, 1872

Genus Microphthalmus Mecznikow, 1865 Microphthalmus arenarius Westheide, 1973

(Figure $2 \mathrm{~B}$ )

Microphthalmus arenarius: Westheide, 1973: 243-248, figures 1-3; Salazar-Vallejo \& Rizzo, 2009: 227-244.

\section{MATERIAL EXAMINED}

Cabo San Francisco Beach, six complete specimens, two anterior and two posterior fragments, 20 March 2009, coll. Berenice Trovant and Santiago Tineo.

\section{DIAGNOSIS}

Up to $1.5 \mathrm{~mm}$ long and $0.3 \mathrm{~mm}$ wide, 22 chaetigers. Preserved specimens brown. Cylindrical body, with three antennae, median one inserted at posterior margin of prostomium. Six pairs of long tentacular cirri inserted on following three segments. A lateral pair of red eyes, located posteriorly in the prostomium. Simple palps with palpophore reduced. Notopodia reduced with compound spinigers, neuropodia with falcigers. An expanded anal plate on the posterior end. The anal plate is smooth and at least as wide as the last chaetiger. Two anal cirri, twice as long as anal plate.

\section{DISTRIBUTION}

Atlantic Ocean: Bermudas.

Family LUMBRINERIDAe Schmarda, 1861 Genus Scoletoma Blainville, 1828 Scoletoma zonata Jonhson, 1901 (Figure 2C)

Lumbriconereis zonata: Johnson, 1901, 408-409, pl. 9, figures 93-100.

Lumbrineris zonata: Hartman, 1944, 146-147; Fauchald, 1970, 112, pl. 18, figure E-I; Fauchald, 1973, 24.

Scoletoma zonata: Carrera-Parra, 2009: 263-276. 

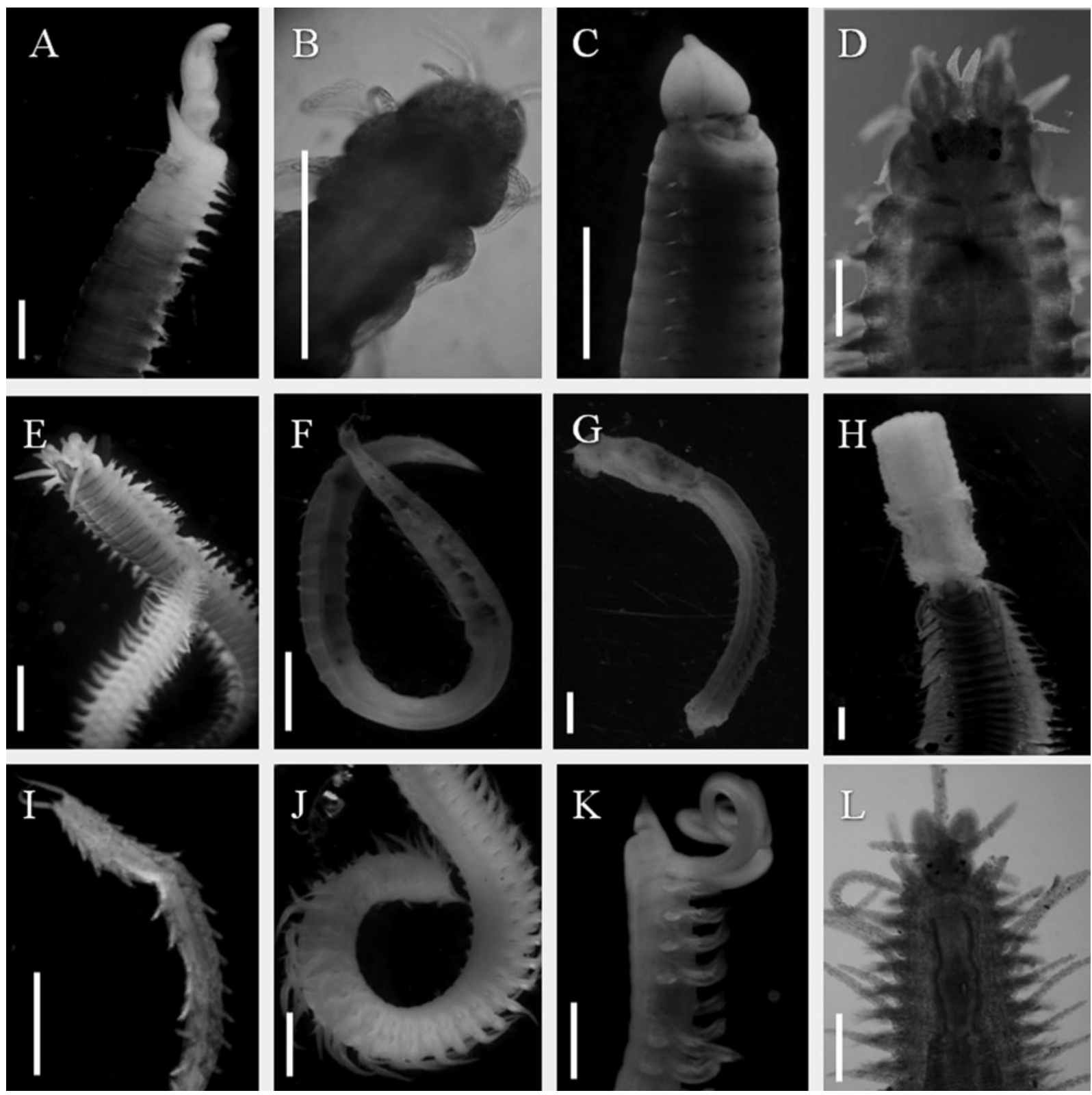

Fig. 2. Polychaetes from Bunche and Cabo San Francisco Beaches, northern Ecuador: (A) Hemipodia pustatula; (B) Microphthalmus arenarius, anterior end, dorsal view; (C) Scoletoma zonata, anterior end, ventral view; (D) Nereis riisei, anterior end, dorsal view; (E) Pseudonereis gallapagensis; (F) Armandia cf. salvadoriana; (G) Euzonus mucronata, whole specimen; (H) Phyllodoce multiseriata; (I) Pisione longispinulata, anterior end, dorsal view; (J) Malacoceros indicus; (K) Scolelepis (Scolelepis) acuta, anterior end, lateral view; and (L) Opisthosyllis arboricola, anterior end, dorsal view. Scale bars: A, C, E, F, G, H, J, K, $\mathrm{L}, 1 \mathrm{~mm} ; \mathrm{I}, 0.5 \mathrm{~mm} ; \mathrm{B}, \mathrm{D}, 0.2 \mathrm{~mm}$.

\section{MATERIAL EXAMINED}

Bunche Beach, one complete specimen, three anterior fragments and one posterior fragment, 21 March 2009, coll. Berenice Trovant and Santiago Tineo.

\section{DIAGNOSIS}

Up to $65 \mathrm{~mm}$ long and $0.5 \mathrm{~mm}$ wide, for 303 chaetigers. Preserved specimens pink to brown, highly iridescent, with a little lateral black intersegmental dot in the middle of each segment throughout body. Subtriangular prostomium. Maxillary formula as follows: with five pairs of maxillae. Carrier jaws attached to the maxilla I throughout the base. Plate connecting the maxilla I with II, broad and slightly sclerotized. Maxilla II as long as maxilla I. Maxilla I with a single tooth, maxilla II with three teeth and accessory lamella. Accessory lamella wider than maxilla II and occupies threequarters of its lateral border. Maxilla III with two teeth, maxilla IV with a single tooth, both fully pigmented. Notopodia reduced with small dorsal cirri. Postchaetal lobe slightly longer than the prechaetal one. Without branchiae. Simple hooded hooks with short cap and simple limbate chaetae from chaetiger 1. Pygidium with two pairs of short anal cirri.

\section{DISTRIBUTION}

Pacific Ocean: United States (Dillon Beach, Tomales Bay, Bodega Lagoon and Puget Sound region), Costa Rica and Panama (Venado Beach). 
Family NEREIDIDAE Lamarck, 1818

Genus Nereis Linnaeus, 1758

Nereis riisei Grube, 1857

(Figure 2D)

Nereis riisei: Grube, 1857: 162; Monro, 1933: 43; Hartman, 1940: 221, lám. 33, figure 37; Fauchald, 1977: 31, figure 8C-E; Taylor, 1984: 31-38, figures 31-36A-G; de León-González \& Solís-Weiss, 2000: 560; Santos \& Lana, 2003: 12, figures 34-40; de León-González et al., 2009: 325-354.

\section{MATERIAL EXAMINED}

Bunche Beach, one incomplete specimen, 21 March 2009, coll. Berenice Trovant and Santiago Tineo.

\section{DIAGNOSIS}

Specimen of $10 \mathrm{~mm}$ long, $1 \mathrm{~mm}$ wide, 55 chaetigers. Preserved specimen unpigmented. Prostomium pentagonal in shape, with two pairs of eyes in trapezoidal arrangement, the posterior pair larger. A pair of short antennae that do not exceed in length the distal part of the palps. Globose palps, subspherical palpostyles. Peristomium as long as the following two segments, but less wide, with four pairs of tentacular cirri, the pair of larger cirri reach chaetiger 3. Pharyngeal paragnaths not visible given the size of specimen. Subconical dorsal ligule, rounded median ligule in all notopodia. Neuropodia with subtriangular ligule on anterior parapodia, and subulate on median and posterior parapodia. Dorsal cirri inserted medially on dorsal ligule, ventral cirri inserted below the ventral ligule. Notochaetae with homogomph spinigers in all parapodia; in median and posterior parapodia one homogomph long bladed falciger appears. Neuropodia with homogomph and heterogomph spinigers and short bladed heterogomph falciger. Pygidium unknown.

\section{DISTRIBUTION}

Pacific Ocean: Mexico (Santa Maria Bay, Gulf of California, Guerrero, Socorro Island), Costa Rica (Nicoya Gulf, Papagayo Gulf), Panama (Gorgona Island, Coiba Island), Colombia (Gorgona Island) and Ecuador (La Libertad, Galapagos Island); Atlantic Ocean: Gulf of Mexico (Florida, Texas, Veracruz, Ciudad del Carmen, Alacranes Reef, Cayo Arcas, Triángulos Oeste, Cayo Nuevo) and Brazil (Maranhão, Piauí, Ceará, Rio Grande do Norte, Paraíba, Pernambuco, Bahia, Alagoas); Caribbean Sea: Bonaire, Anguilla, St Eustatius, Aruba, Curaçao, Barbados, St Vincent, Grenada, Barbuda, Antigua, Jamaica, Cuba (La Habana Bay), Venezuela (Cariaco Gulf), Colombia (Nenguangue Bay), Panama (Galeta Reef) and Mexico (Nicchehabin Reef, east of Allen Point, Ascencion Bay and Cozumel Island).

Family NEREIDIDAE Lamarck, 1818

Genus Pseudonereis Kinberg, 1866

Pseudonereis gallapagensis Kinberg, 1866

(Figure 2E)

Pseudonereis gallapagensis: Fauvel, 1939: 328; 1953: 215, figure 110A-C; Hartman, 1940: 231; Rioja, 1960: 297; Hartmann-Schröder, 1962: 432; Wesenberg-Lund, 1962: 84, figure 32; Imajima, 1972: 97, figure 28A-J; Fauchald, 1977: 32, figure $4 \mathrm{G}-\mathrm{H}$; Liñero-Arana \& Reyes-Vázquez, 1979: 8, figures 1-10; Rozbaczylo \& Bolados, 1980; 219, figure A-D; Wu et al., 1985: 220, figure 124A-F; Hylleberg et al., 1986:
14, figure 8A-P; Bakken \& Wilson, 2005: 534; de León-González et al., 2009: 325-354.

\section{MATERIAL EXAMINED}

Cabo San Francisco Beach, one complete specimen, 20 March 2009, coll. Berenice Trovant and Santiago Tineo.

\section{DIAGNOSIS}

Specimen of $11 \mathrm{~mm}$ long, $0.5 \mathrm{~mm}$ wide, 61 chaetigers. Preserved specimen light brown. Sub-pentagonal prostomium. A pair of antennae and a pair of globose palps. Two pairs of black eyes. Four pairs of tentacular cirri, dorsal one longest. Birramous parapodia. Cirriform dorsal cirri in all parapodia. All notopodia highly developed, with ligule, lobes and chaetae. Pharynx armed in both rings, maxillary ring, Group I, two small cones; Group II, three pectins; Group III, four pectins in oval arrangement; Group IV, eight small cones and 20 wide basally, in the distal region, four in accordance pectins' growing arrangement. Oral ring, Group V, one big cone; Group VI, a short transverse bar into a cone shape; Groups VII-VIII, 22 cones in two lines. Dorsal cirrus inserted distal to the dorsal ligula in posterior parapodia. Notopodia with homogomph spinigers and neuropodia with homogomph spinigers and heterogomph falcigers. Pygidium with two ventrolateral anal cirri.

\section{DISTRIBUTION}

Pacific Ocean: Ecuador (Galapagos Islands), Peru and Chile; Atlantic Ocean: Gulf of Mexico, Panama, Brazil, South Africa; Indian Ocean.

Family OPHELIIDAE Malmgren, 1867

Genus Armandia Filippi, 1861

Armandia cf. salvadoriana Hartmann-Schröder, 1956 (Figure 2F)

Armandia salvadoriana: Hartmann-Schröder 1956: 95, figures $6-8$.

\section{MATERIAL EXAMINED}

Bunche Beach, eight complete specimens, 21 March 2009, coll. Berenice Trovant and Santiago Tineo.

\section{DIAGNOSIS}

Up to $13 \mathrm{~mm}$ long and $1 \mathrm{~mm}$ wide, 35 chaetigers. Preserved specimens unpigmented. Elongate body with a lateral groove. Prostomium long, conical and acuminate; large nuchal organs, without ocelli. Cirriform branchiae, longer than notochaetae, recurved over the body, present from chaetiger two to the end of body, although in some individuals they may be absent in the last chaetigers. Anal funnel long with 17-19 rings, marginal festoon with 6-7 lanceolate papillae and with a long medial cirri. With 23-25 pairs of lateral eyes starting from chaetigers $6-7$.

\section{DISTRIBUTION}

Pacific Ocean: El Salvador (San Juan, Pajarita and Madre-Sal) and Costa Rica (Golfo de Nicoya).

\section{REMARKS}

In the original description of $A$. salvadoriana Hartmann-Schröder, 1956, the number of pairs of eyes is 15, while our specimens have 23-25 pairs of eyes. Type material of A. salvadoriana was not observed; however, the 
Ecuadorian form is similar to the El Salvadorian one in all the remaining characters.

$$
\begin{gathered}
\text { Family OPHELIIDAE Malmgren, } 1867 \\
\text { Genus Euzonus Grube, } 1866
\end{gathered}
$$

Euzonus mucronata Treadwell, 1914

(Figure $2 \mathrm{G}$ )

Euzonus mucronata: Blake, 2000: 152-153, figure 7.2A-C, F.

\section{MATERIAL EXAMINED}

Bunche Beach, six complete specimens, 21 March 2009, coll. Berenice Trovant and Santiago Tineo.

\section{DIAGNOSIS}

Up to $14 \mathrm{~mm}$ long and $0.5 \mathrm{~mm}$ wide, 38 chaetigers. Live specimens unpigmented except for the pink gut; preserved specimens unpigmented. Body divided into three regions: cephalic region that includes the prostomium and the first two chaetigers; a thoracic region that includes the chaetigers 3-11 and the abdominal region that comprises two chaetigers without branchiae, 18 chaetigers with branchiae and eight post-branchial segments. Cylindrical body on the anterior segments, with ventral groove on branchial region that continues to the posterior end. Prostomium small and conical, buccal organs present. Parapodia birramous; all chaetae are capillaries; notochaetae longer than neurochaetae. Smooth branchiae with two branches. Pygidium with a long ventral cirrus and seven pairs of digitiform lateral lobes.

\section{DISTRIBUTION}

Pacific Ocean: Canada, United States (Dillon Beach) and Mexico.

Family PHYLLODOCIDAE Örsted, 1843

Genus Phyllodoce Lamarck, 1818

Phyllodoce multiseriata Rioja, 1941

(Figure 2H)

Phyllodoce (Anaitides) multiseriata: Salazar-Vallejo, 1989, 45. Phyllodoce multiseriata: Glockner-Fagetti, 2009: 409-424.

\section{MATERIAL EXAMINED}

Bunche Beach, eight complete specimens, two anterior and four median fragments, 21 March 2009, coll. Berenice Trovant and Santiago Tineo.

\section{DIAGNOSIS}

Up to $45 \mathrm{~mm}$ long and $1.5 \mathrm{~mm}$ wide, 155 chaetigers. Live specimens greenish with a brown intersegmental transverse band; preserved specimens with the same pattern colour. Prostomium chordate. With four antennae and nuchal papilla. A pair of red eyes. Four pairs of tentacular cirri. Pharynx with conical papillae arranged regularly in the basal ring. First two segments fused dorsally. Uniramous parapodia, rounded dorsal cirri, pyriform ventral cirri, smaller than the dorsal one. Neuropodia with spinigers. Pygidium with two anal cirri.

\section{DISTRIBUTION}

Pacific Ocean: Canada (British Columbia) and Mexico (La Aguada, Acapulco and Guerrero).

Family PISIONIDAE Ehlers, 1901

Genus Pisione Grube, 1857

\section{Pisione longispinulata Aguado \& San Martín, 2004}

(Figure 2I)

Pisione longispinulata: Aguado \& San Martín, 2004: 75-78, figures 2-3.

\section{MATERIAL EXAMINED}

Cabo San Francisco Beach, 82 complete specimens, nine anterior, two median and four posterior fragments, of which 29 were males (26 complete specimens and three anterior fragments); 20 March 2009, coll. Berenice Trovant and Santiago Tineo.

\section{DIAGNOSIS}

Up to $3.5 \mathrm{~mm}$ long, $0.5 \mathrm{~mm}$ wide, 36 chaetigers. Preserved specimens unpigmented. Body elongate and filiform. Small prostomium, buccal segment directed forward and partially fused to prostomium; without chaetae. A long pair of smooth palps. Buccal segment with dorsal tentacular cirri directed forward, elongated (approximately one-third of the length of the palps); short globular ventral cirri. This segment carries a pair of buccal aciculae that arise internally at the base of the dorsal cirri, firm, slightly emerging and distally expanded. Globular dorsal cirri with a distal papilla small and spherical. A pair of eyes located between chaetigers 2-3. Reversible pharynx, with two pairs of chitinous jaws seen by transparency. Brown mandibles occur in the third chaetiger. Parapodia with four chaetae, one simple chaetae and three falcigers (the first longest) with long secondary spines. Notoacicula embedded throughout the entire body, not protruding. The 29 males had a pair of copulatory organs located between chaetigers 12 and 27, and three of them also had a second pair located between chaetigers 25 and 28 . Rounded pygidium with a pair of long anal cirri.

\section{DISTRIBUTION}

Pacific Ocean: Panama (Coiba Island).

\section{REMARKS}

Aguado \& San Martín (2004) described Pisione longispinulata based on two males and found that they had one copulatory organ between segments 18 and 20 , while in our specimens we found the first pair between segments 13 and 28 . Furthermore, three specimens presented a second pair of copulatory organs. Given the number of specimens we have been able to observe, we believe there might be a wider variation in the number and in the distribution of the copulatory organs in this species.

Family SPIONIDAE Grube, 1850

Genus Malacoceros Quatrefages, 1843

Malacoceros indicus (Fauvel, 1928)

(Figure 2J)

Malacoceros indicus: Pettibone, 1963: 99; Day, 1967: 477, figure 18.5p-u; Blake, 1983: 219; 1996: 105-107, figure 4.4; Delgado-Blas, 2009: 589-615.

MATERIAL EXAMINED

Bunche Beach, one anterior fragment, 21 March 2009, coll. Berenice Trovant and Santiago Tineo. 


\section{DIAGNOSIS}

Specimen of $25 \mathrm{~mm}$ long, $1 \mathrm{~mm}$ wide. Live specimen unpigmented except for the green digestive tube, preserved specimen unpigmented. Body wide anteriorly. Prostomium bell-shaped with frontal horns. A pair of red eyes. With cirriform branchiae from first chaetiger. Branchiae basally fused to postchaetal lamellae and short on posterior region of the body. Capillary chaetae simple. With neuropodial hooks. Hooded hooks bidentate from chaetigers 30 to 50 . Pigidium unknown.

\section{DISTRIBUTION}

Pacific Ocean: Chile; Atlantic Ocean: Gulf of Mexico, South Africa; Indian Ocean: Gulf of Manaar, Mozambique and New Caledonia.

\section{Family SPIONIDAE Grube, 1850 \\ Genus Scolelepis Blainville, 1828 \\ Scolelepis (Scolelepis) acuta Treadwell, 1914}

(Figure 2K)

Scolelepis (Scolelepis) acuta: Delgado-Blas, 2006: 79-81, figure 2; Delgado-Blas, 2009: 589-615.

MATERIAL EXAMINED

Bunche Beach, five anterior fragments and one median fragment, 21 March 2009, and Cabo San Francisco Beach, seven anterior fragments, 20 March 2009, coll. Berenice Trovant and Santiago Tineo.

\section{DIAGNOSIS}

Up to $11 \mathrm{~mm}$ long and $1 \mathrm{~mm}$ wide. Preserved specimens unpigmented. Body elongated, conical prostomium and short peristomium. Two pairs of red eyes. Two long tentacular palps, slightly rugose, with two longitudinal rows of cilia. The first segment with short neurochaetae and without notochaetae. Chaetiger 5 without modified chaetae. Postchaetal lamella associated with notopodia and neuropodia of anterior region. All lamellae decrease in size toward posterior region. Branchiae from second chaetiger, basally fused to the lamella in most parapodia. Simple chaetae and neuropodial hooded hooks with three small teeth. Pygidium unknown.

\section{DISTRIBUTION}

Pacific Ocean: United States (San Diego, California).

Family SYLLIDAE Grube, 1850

Genus Opisthosyllis Langerhans, 1879

Opisthosyllis arboricola Hartmann-Schröder, 1959

(Figure $2 \mathrm{~L}$ )

Opisthosyllis arboricola: Góngora-Garza, 2009: 615-639.

\section{MATERIAL EXAMINED}

Bunche Beach, one anterior and posterior fragment, 21 March 2009 and Cabo San Francisco Beach, one complete specimen, 20 March 2009, coll. Berenice Trovant and Santiago Tineo.

\section{DIAGNOSIS}

Up to $3 \mathrm{~mm}$ long, $0.5 \mathrm{~mm}$ wide, 50 chaetigers. Preserved specimens unpigmented. Pentagonal prostomium. Two pairs of eyes in trapezoidal arrangement. With three articulated antennae in the anterior region of the prostomium. Median antennae with 14 articles. Lateral antennae with ten articles, twice the length of the prostomium. Two free subtriangular palps. Anterior-body with long dorsal cirri formed by $14-$ 22 articles; mid-body with long dorsal cirri with 16-17 articles, and posterior dorsal cirri with 12-14 articles. Triangular ventral cirri. Ventral parapodial lobe short, subconical and truncated, with prechaetal and postchaetal extension smaller than the last one. Anterior-body with 10-12 falcigers per fascicle, unidentate with well-defined tertiary teeth. Median-body with 7-9 falcigers per fascicle, dorsal falcigers with tertiary teeth and ventral smooth, all unidentate. Porsterior-body with 5-7 falcigers per fascicle, unidentate, smooth, without tertiary teeth. Pharynx wide, occupies almost the entire width of the body, as long as 7-8 segments. With middle-dorsal tooth in a posterior position. Middle-dorsal tooth single, large and yellow, in a posterior position. Proventricle as long as $8-9$ segments, no observation of muscle cell ring. Dorsal acicular chaetae with rounded end and ventral acicular chaetae unidentate and smooth. The anterior region of the body with three aciculae, the median region with two aciculae and only one in the posterior region very close to the pygidium. Pygidium with two long articulate anal cirri. The cirri with approximately 12 articles each.

\section{DISTRIBUTION}

Atlantic Ocean: El Salvador (Estero Jaltepeque and Golfo de Fonseca)

\section{ACKNDWLEDGEMENTS}

This research was conducted by Berenice Trovant as part of the requirements for an MSc degree in 'Biodiversity in tropical areas and its conservation' at the Universidad Internacional Menéndez Pelayo (UIMP, Spain), a Masters programme funded by the Spanish National Research Council (CSIC, Spain) and carried out at the Universidad Central del Ecuador. This work would not have been possible without the help of the following people: Trovant's family, S.A. Tineo, J.M. Orensanz, J. Muñoz, G. Góngora, L.F. Carrera-Parra, D. Salcedo, V. Radashevsky, G. San Martín, A. Rizzo, S. Salazar-Vallejo, J.M. Serrano, F. Villamar, M. Cornejo, V. Carvajal, J. Santiana, C. Crowe, S. Heaslip and the staff of the Biological Reserve 'The Congal': Andrés, Fredy, Karina and Vicente. Also, we are grateful to Vivianne Solis-Weiss and the two anonymous referees that contributed substantially to improve the manuscript.

\section{REFERENCES}

Aguado M.T. and San Martín G. (2004) Pisionidae (Polychaeta) from Coiba National Park with the description of a new species and two new reports of Pisione. Journal of the Marine Biological Association of the United Kingdom 84, 73-79.

Bakken T. and Wilson R.S. (2005) Phylogeny of nereidids with paragnaths. Zoologica Scripta 34, 507-547.

Blake J.A. (1983) Polychaetes of the Family Spionidae from South America, Antarctica, and adjacent seas and islands. Biology of the Antarctic Seas XIV. Antarctic Research Series 39, 205-288.

Blake J.A. (1996) Family Spionidae Grube, 1850. In Blake J.A., Hilbig B. and Scott P.H. (eds) Taxonomic atlas of the benthic fauna of the Santa Maria Basin and western Santa Barbara Channel. 6-The 
Annelida Part 3. Polychaeta: Orbiniidae to Cossuridae. Santa Barbara, CA: Santa Barbara Museum of Natural History, pp. 81-223.

Blake J.A. (2000) Family Opheliidae Malmgren 1867. In Blake J.A., Hilbig B. and Scott P.V. (eds) Taxonomic atlas of the benthic fauna of the Santa Maria Basin and western Santa Barbara Channel. The Annelida Part 4. Santa Barbara, CA: Santa Barbara Museum of Natural History, pp. 145-168.

Böggemann M. and Eibye-Jacobsen D. (2002) The Glyceridae and Goniadidae (Annelida: Polychaeta) of the Bioshelf Project, Andaman Sea, Thailand. Phuket Marine Biological Center Special Publication 24, 149-196.

Carrera-Parra L.F. (2009) Lumbrineridae Schmarda, 1961. 25: 263-275. In de León-González J.A., Bastida-Zavala J.R., Carrera-Parra L.F., García-Garza M.E., Peña-Rivera A., Salazar-Vallejo S.I. and Solís-Weiss V. (eds) Poliquetos (Annelida: Polychaeta) de México y América Tropical. Monterrey, México: Universidad Autónoma de Nuevo León, 737 pp.

Cruz M., De Gonzáles M., Gualancañay E. and Villamar F. (1980) Lista de la Fauna Sublitoral Bentónica del Estero Salado Inferior, Ecuador. Acta Oceanográfica del Pacífico 1, 82-96.

Day J.H. (1967) A monograph on the Polychaeta of southern Africa. London: British Museum of Natural History Publication.

Delgado-Blas V.H. (2006) Partial revision of Scolelepis (Polychaeta: Spionidae) from the Grand Caribbean region, with the description of two new species and a key to species recorded in the area. Contributions to Zoology 75, 75-97.

Delgado-Blas V.H. (2009) Spionidae Grube, 1850. In de León-González J.A., Bastida-Zavala J.R., Carrera-Parra L.F., García-Garza M.E., Peña-Rivera A., Salazar-Vallejo S.I. and Solís-Weiss V. (eds) Poliquetos (Annelida: Polychaeta) de México y América Tropical. Monterrey, México: Universidad Autónoma de Nuevo León, pp. 589-614.

Fauchald K. (1970) Polychaetous annelids of the families Eunicidae, Lumbrineridae, Iphitimidae, Arabellidae, Lysaretidae and Dorvilleidae from western Mexico. Allan Hancock Monographs Marine Biology 5.

Fauchald K. (1973) Polychaetes from central American sandy beaches. Bulletin of the Southern California Academy of Sciences 72, 19-31.

Fauchald K. (1977) The Polychaete worms, definitions and keys to the Orders, Families and Genera. Natural History Museum of Los Angeles County, Allan Hancock Foundation and University of Southern California. Science Series no. 28.

Fauvel P. (1939) Annélides polychétes de IÍndochine recueillies par M.C. Dawydoff. Commentationes. Pontificia Academia Scientia 3, 243-368.

Fauvel P. (1953) The fauna of India including Pakistan, Ceylon, Burma and Malaya: Annelida Polychaeta. Allahabad: The Indian Press Ltd.

Friedrich H. (1956) Mitteilungen über neue und wenig bekannte Polychaeten aus Mittel und Südamerika. Senckenbergiana Biologica $37,57-68$.

Glockner-Fagetti A. (2009) Phyllodocidae Örsted, 1843. In de León-González J.A., Bastida-Zavala J.R., Carrera-Parra L.F., García-Garza M.E., Peña-Rivera A., Salazar-Vallejo S.I. and Solís-Weiss V. (eds) Poliquetos (Annelida: Polychaeta) de México y América Tropical. Monterrey, México: Universidad Autónoma de Nuevo León, pp. 409-424.

Góngora-Garza G. (2009) Syllidae, Grube 1850. In de León-González J.A., Bastida-Zavala J.R., Carrera-Parra L.F., García-Garza M.E., Peña-Rivera A., Salazar-Vallejo S.I. and Solís-Weiss V. (eds) Poliquetos (Annelida: Polychaeta) de México y América Tropical. Monterrey, México: Universidad Autónoma de Nuevo León, pp. $615-639$.
Grube A.E. (1857) Annulata Örstediana. Enumeratio Annulatorum, quac in itinere per Indiam occidentalem et Americam centralem annis 1845-1848 suscepto legit cl. A. S. Örsted, adjectis speciebus nonnullis a cl. H. Kröyero in itinere ad Americam meridionalem collectis. Videnskabelige Meddelelser fra Dansk naturhistorisk Forening $i$ Köbenhavn, 1857, 158-166.

Hartman O. (1939) Polychaetous Annelids. Part I. Aphroditidae to Pisionidae. Allan Hancock Pacific Expeditions 7.

Hartman O. (1940) Polychaetous Annelids. Part II. Chrysopetalidae to Goniadidae. Allan Hancock Pacific Expeditions 7.

Hartman O. (1944) Polychaetous annelids. Part V. Eunicea. Allan Hancock Pacific Expeditions 10.

Hartmann-Schröder G. (1956) Neue Armandia-arten (Opheliidae, Polychaeta) aus Brasilien und El Salvador. Beiträge zur Neotropischen, Fauna 1, 63-68.

Hartmann-Schröder G. (1959) Zur Ökologie der Polycheten des Manfrove-Estero-Gebietes von El Salvador. Beiträge zur Neotropischen, Fauna 1, 69-183.

Harmann-Schröder G. (1962) Zur Kenntnis der Nereiden Chiles (Polychaeta errantia), mit Beschreibung epitoker Stadien einiger Arten und der Jugend-entwicklung von Perinereis vallata (Grube). Sonderdruck aus Zoologischer Anzeiger 168, 389-441.

Hartmann-Schröder G. (1965) Zur Kenntnis des Sublitoralis der chilenischen Küste unter besonderer Berücksichtigung der Polychaeten und Ostracoden. Mittelungen aus dem Hamburgishchen Zoologischen Museum und Institut 62, 36-305.

Hylleberg J., Nateewathana A. and Bussarawit S. (1986) Polychaetes from Thailand, Nereidae (Part 1): Perinereis and Pseudonereis with notes on species of commercial value. Phuket Marine Biological Center. Research Bulletin 1, 1-22.

Imajima M. (1972) Review of the annelid worms of the family Nereidae of Japan, with descriptions of five new species or subspecies. Bulletin of the National Science Museum 15, 37-153.

Johnson H.P. (1901) The Polychaeta of the Puget Sound region. Proceedings of the Boston Society for Natural History 29, 381-437.

León-González J.A. de, Bastida-Zavala J.R., Carrera-Parra L.F., García-Garza M.E., Peña-Rivera A., Salazar-Vallejo S.I. and Solís-Weiss V. (2009) Poliquetos (Annelida: Polychaeta) de México y América Tropical. Monterrey, México: Universidad Autónoma de Nuevo León.

León-González J.A. de, Cornejo-Rodriguez M.H. and Degraer S. (2008) A new species of Australonuphis (Polychaeta: Onuphidae) from the eastern Pacific. Journal of the Marine Biological Association of the United Kingdom 88, 739-742.

León-González J.A. de and Solís-Weiss V. (2000) A review of the polychaete family Nereididae from western Mexico. Bulletin of Marine Science 67, 549-569.

Liñero-Arana I. and Reyes-Vázquez G. (1979) Nereidae (Polychaeta: Errantia) del Golfo de Cariaco, Venezuela. Boletín Instituto Oceanográfico Universidad de Oriente 18, 3-12.

Monro C.C.A. (1933) The Polychaeta Errantia collected by Dr C. Crossland at Colón, in the Panama Region, and the Galapagos Islands during the expedition of the S.Y. St. George. Proceedings of the Zoological Society of London 1933, 1-96.

Pettibone M.H. (1963) Revision of some genera of polychaete worms of the family Spionidae, including the description of a new species of Scolelepis. Proceedings of the Biological Society of Washington 76, 89-104. 
Rioja E. (1960) Adiciones a la fauna de anélidos poliquetos de las costas orientales de México. Anales del Instituto de Biología (México) 31, 289-316.

Rozbaczylo N. and Bolados J. (1980) Nereidos de Iquique, Chile (Polychaeta: Nereidae). Boletín del Museo de Historia Natural Chile $37,205-224$.

Salazar-Vallejo S.I. (1989) Enrique Rioja y su contribución al estudio de los poliquetos (Annelida: Polychaeta) en México. Brenesia 30, 39-65.

Salazar-Vallejo S.I. and Rizzo A.E. (2009) Hesionidae Grube, 1850. In de León-González J.A, Bastida-Zavala J.R., Carrera-Parra L.F., García-Garza M.E., Peña-Rivera A., Salazar-Vallejo S.I. and Solís-Weiss V. (eds) Poliquetos (Annelida: Polychaeta) de México y América Tropical. Monterrey, México: Universidad Autónoma de Nuevo León, pp. 227-244.

Santos C.S.G. and Lana P.C. (2003) Nereididae (Polychaeta) da costa nordeste do Brasil. III. Gêneros Ceratonereis e Nereis. Iheringia, Séries Zoology 93, 5-22.

Taylor J.L. (1984) Nereidae Johnston 1845. In Uebelacker J.M. and Johnson P.G. (eds) Taxonomic guide to the polychaetes of the northern Gulf of Mexico. Mobile, AL: Barry A. Vittor and Associates, v. 5, pp. 1-42.

Villamar F. (1983) Poliquetos del Golfo de Guayaquil. Acta Oceanográfica del Pacífico INOCAR 2, 659-733.

Villamar F. (2006) Estudio Taxonómico y Distribución de los Poliquetos Bentónicos en la zona del intermareal de las Provincias de Esmeraldas y Manabí (Ecuador). Acta Oceanográfica del Pacífico INOCAR 13, $169-197$.

Villamar F. and Cruz M. (2007) Poliquetos y Moluscos macrobentónicos de la zona intermareal y submareal en la provincia de Guayas (Monteverde, Ecuador). Acta Oceanográfica del Pacífico INOCAR 14, $147-153$.

Wesenberg-Lund E. (1962) Polychaeta Errantia. Reports of the Lund University Chile Expedition 1948-1949. Lunds Universitets Arsskrift 12.

Westheide W. (1973) Zwei neue interstitielle Microphthalums-Arten (Polychaeta) von den Bermudas. Mikrofauna des Meeresbodens 14, $241-252$.

and

Wu B., Ruiping S. and Yang U.J. (1985) The Nereidae (polychaetous annelids) of the Chinese coast. Beijing: China Ocean Press, and Berlin: Springer-Verlag, vi.

\section{Correspondence should be addressed to:}

Berenice Trovant

Centro Nacional Patagónico (CONICET)

Boulevard Brown 2915

U9120ACF Puerto Madryn

Chubut, Argentina

email: berenicetrovant@cenpat.edu.ar 